\title{
Human health hazards of persistent inorganic and carbon nanoparticles
}

\author{
L. Reijnders
}

Received: 11 October 2011/Accepted: 20 January 2012/Published online: 8 February 2012

(C) Springer Science+Business Media, LLC 2012

\begin{abstract}
Persistent inorganic and carbon nanoparticles are increasingly engineered for applications and may also be present in conventional materials such as carbon black. Furthermore, they may originate from conventional non particulate materials by processes such as wear and tear. Persistent inorganic and carbon nanoparticles can be hazardous to humans. Relatively much research regards the hazards of inhaled nanoparticles. These may give rise to respiratory disease and to negative effects on other organs, including the cardiovascular system. Determinants of risk of inhaled nanoparticles include: number, size, surface characteristics, shape, structure, and the formation of assemblages. These determinants should preferentially be considered in exposure metrics. A major molecular mechanism underlying the inhalation hazard of nanoparticles is the generation of reactive oxygen species, but other mechanisms such as interactions with proteins and DNA may also contribute. Health hazards may also be linked to ingestion of persistent inorganic and carbon nanoparticles, dermal exposure and exposure of the eye. Standards for workplace exposure to persistent inorganic and carbon are currently emerging and there are options for hazard reduction by elimination and substitution of hazardous nanoparticles and by engineering controls.
\end{abstract}

\section{Introduction}

Nanoparticles are often defined as particles with a diameter $<100 \mathrm{~nm}$ in at least one dimension [e.g., 1-4]. Regarding

L. Reijnders $(\bowtie)$

IBED, University of Amsterdam, Science Park 904, P.O. Box

94248, 1090 GE Amsterdam, The Netherlands

e-mail: 1.reijnders@uva.nl hazard, the potential to harm, or risk, the chance that harm occurs, this definition may be at least somewhat arbitrary. Auffan et al. [5] have suggested that inorganic nanoparticles with diameters less than 20-30 nm may have physicochemical properties (such as thermodynamic instability, solubility and solid phase transitions) which may cause their hazard(s) to be different from larger sized particles, including nanoparticles in the $30-100 \mathrm{~nm}$ range. Jiang et al. [6] studying the generation of hazardous reactive oxygen species (ROS), which is an important determinant of hazard [1-3, and references therein], by titania nanoparticles found negligible generation of ROS when the titania nanoparticles were smaller than $10 \mathrm{~nm}$, but substantial generation of ROS at nanoparticle sizes over $10 \mathrm{~nm}$.

Attention has also been drawn to the hazard of particles which are somewhat larger than $100 \mathrm{~nm}$. For instance, it has been found that hazard linked to the generation of reactive oxygen species under solar irradiation is similar for $\mathrm{TiO}_{2}$ particles with diameters of $\sim 15$ and $120 \mathrm{~nm}$ [7]. Also, particles measured as being larger than $100 \mathrm{~nm}$ in, e.g., workplaces may well be assemblages (aggregates or agglomerates) of nanoparticles [8], which, as will be discussed in detail later, may be characterized by substantial hazard when the surface of the component nanoparticles remains available for reactivity. Against this background it has been argued that in view of hazard the definition of nanoparticles should extend to larger diameters, e.g., to about $300 \mathrm{~nm}$ [8]. Here, in a first approximation, the word nanoparticle will refer to a particle with a diameter $<100 \mathrm{~nm}$ in at least one dimension, but when appropriate in view of hazard, the scope of this review will be extended to particles which are larger. Nonlinear relations between size of nanoparticles $<100 \mathrm{~nm}$ and hazard will be discussed. 
In this review, the focus will be on persistent inorganic and carbon nanoparticles. Persistent means in this case that the nanoparticles are poorly soluble or insoluble in water. Thus, for instance, sodium carbonate nanoparticles will not be included here as these are not poorly soluble or insoluble in water.

The carbon nanoparticles considered here include carbon nanotubes, nanoparticulate carbon black, graphene nanoplatelets, carbon nanofibers, and fullerenes.

In relation to materials, it may be noted that persistent inorganic and carbon nanoparticles may be present in conventional commercial materials [8, 9]. Examples thereof are carbon black and the paint-additives talc and calcium carbonate, which may be at least partly nanoparticulate [8, 9, and references therein].

Persistent nanoparticles are also increasingly engineered for a variety of applications [1-3, 8-19, and references therein]. Engineered nanoparticles in this category are often composed of the substances indicated in Box 1 [1-3, 8-19, and references therein].

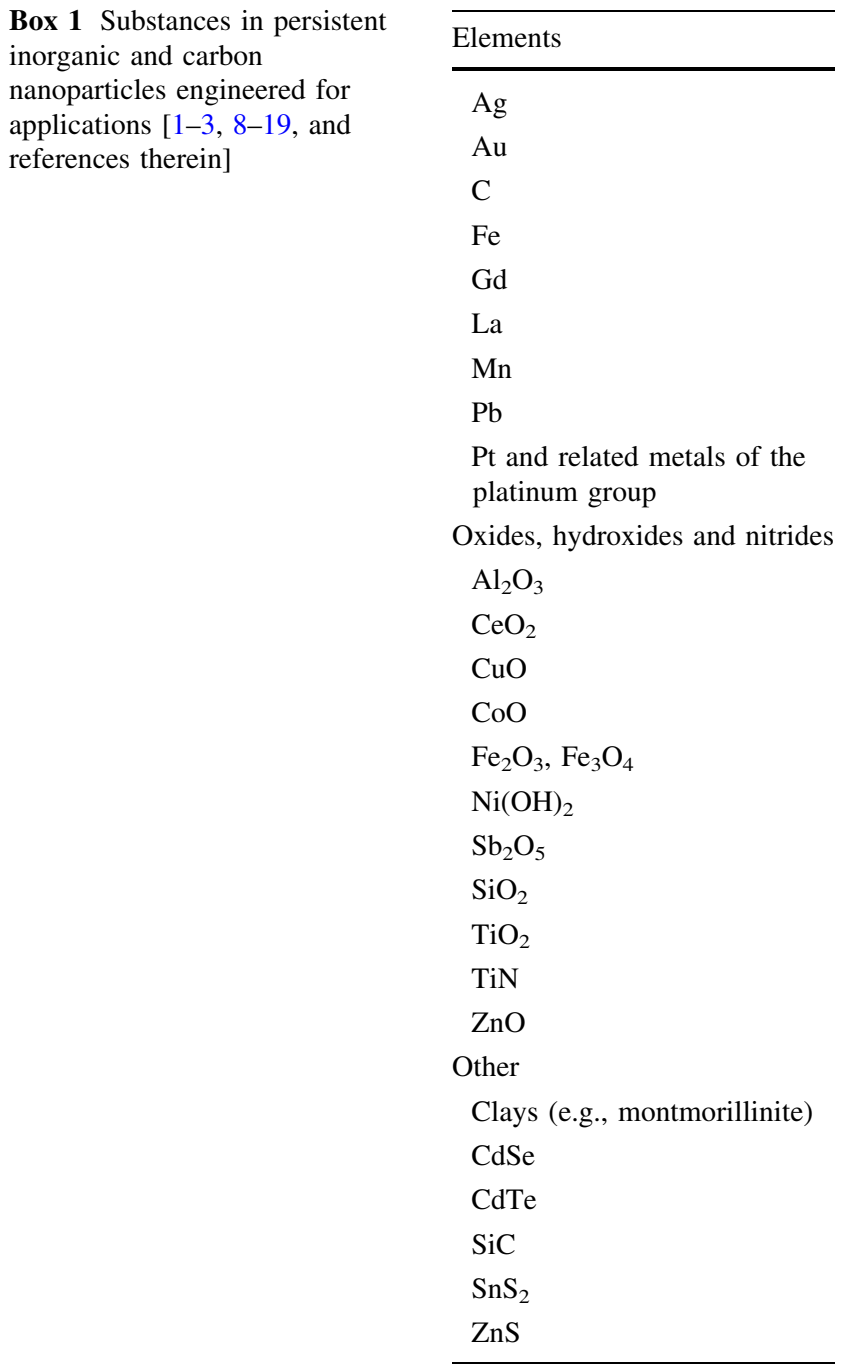

Persistent engineered nanoparticles may be applied without further modification (e.g., nanoparticulate $\mathrm{SiO}_{2}$ as glidant in powders, and nano- $\mathrm{CeO}_{2}$ in diesel fuels) [11]. Another possibility is that persistent engineered nanoparticles are doped, coated, capped or functionalized with other substances [e.g., 15, 16]. Nanoparticles may also be embedded in, or used as coating on, materials. Examples are: $\mathrm{TiO}_{2}$ or $\mathrm{Pt}$ nanoparticles embedded in substrates for heterogeneous catalysis, Ag nanoparticle coatings on dressings and catheters and nanoclay incorporated in organic polymers to improve fire resistance [11, and references therein]. The product life cycles after embedding of nanoparticles or their use as coating, up to final disposal, might give rise to the release of these nanoparticles $[9,11]$. An example is the loss of nanoparticles from Ag nanoparticle coated textiles during washing [11, and references therein]. Another case in point is the release of $\mathrm{TiO}_{2}$ from polymeric matrices linked to polymer degradation [12]. It may also be that particles released from the material with embedded nanoparticles do contain other substances besides the embedded nanoparticles, but are still nanoparticulate [8, 10-12, and references therein]. It might furthermore be that the embedding is such that nanoparticle release from nanocomposites does not specifically concern the nanoparticles included in the product, but is rather linked to changes in product characteristics such as density. For instance, van Broekhuizen et al. [20] have suggested that increased nanoparticle generation by drilling concrete made from mixes containing nano- $\mathrm{SiO}_{2}$ is rather linked to increased density of the concrete.

Finally, persistent inorganic nanoparticles can originate in conventional non-nanoparticulate materials by processes, such as irradiation, wear and tear. For instance, Scymczak et al. [21] found significant releases of $\mathrm{Cu}$ nanoparticles from electromotors. Barthel et al. [22] concluded that laser printers emit measurable quantities of solid inorganic nanoparticles and carbon nanoparticles are produced in diamond processing [23]. Metal-on-metal hip resurfacing may lead to the release of metal nanoparticles [24].

During their life cycle, nanoparticles may absorb toxicants which, after absorption, remain bio-available, e.g., to humans after inhalation or to other organisms [e.g., 25]. The implications thereof will not be discussed here.

In past standard setting by government agencies, it was often assumed that the hazard of inorganic particles is dependent on chemical composition, but independent of size and that risk depends on exposure dose in terms of mass [2]. A notable exception to the use of mass in standards regards asbestos. For asbestos air quality standards can refer to particle number and not to mass [10, and references therein]. The assumption that chemical composition and mass are the only determinants of nanoparticle 
hazard is now known to be incorrect, to the extent that toxicity is not completely driven by chemistry $[1-3,14$, and references therein]. As will be pointed out in this "Emerging workplace standards" section, new nanoparticle-specific standards are gradually emerging, though it may be noted that current standards of government agencies which are applied to nanoparticle exposure are still often based on the assumption that only mass and chemical composition matter [9, 10].

Partly as a consequence of the longstanding and widely held assumption that size does not matter, the study of nanoparticulate hazards is so far limited [1-3, 14, 15, 26, and references therein]. In this article, currently available research on hazards and health risks of exposure to persistent inorganic and carbon nanoparticles will be reviewed. Most of this research regards hazards to mammals and mammalian cells which is relevant to human health hazards. Most of the studies relevant to establishing human health hazards deal with inhalation of nanoparticles [1-3, and references therein]. The emphasis of this review will be on determinants of human health hazards and the underlying molecular mechanisms. Apart from human health hazards nanoparticles may also give rise to ecotoxicity. Data about ecotoxicity even more fragmentary than the study of human health hazards [e.g., 27, 28, and references therein]. Moreover, a review of ecotoxicity studies regarding nano- $\mathrm{TiO}_{2}$, the best studied engineered nanoparticle in this respect [27], concluded that these studies did not allow for characterization of the major determinants of ecotoxicity [29]. Against this background hazards for other organisms than humans will not be considered here.

Secondly in this article, current approaches to standard setting for nanoparticles by government agencies will be outlined, and finally, options for human health hazard reduction will be considered.

\section{Types of exposure to persistent inorganic and carbon nanoparticles relevant to human health}

Several types of human occupational, environmental, and consumer exposure to persistent engineered nanoparticles can be distinguished. Exposure may be linked to inhalation, ingestion, dermal contact, and eye contact. There may also be exposure linked to the application of persistent engineered nanoparticles for medical purposes inside the body. The human health hazards of the latter will not be specifically discussed here.

Available research regarding human health hazards of exposure to persistent engineered inorganic and carbon nanoparticles will be discussed in what follows.
Determinants of human inhalation hazards of persistent engineered inorganic and carbon nanoparticles

Primary persistent engineered nanoparticles having a size $<100 \mathrm{~nm}$ in at least one dimension penetrate relatively easily deep into the lungs and can be deposited there [e.g., 2, 3, and references therein].

Inhalation hazards of persistent engineered inorganic and carbon nanoparticles firstly regard the respiratory system. Potential effects on the lungs include damage to membranes, cytotoxicity, genotoxicity, apoptosis (induced programmed cell death), necrosis (cell death due to toxic interference with vital cell functions), inflammation, fibrosis, and cancer [1-3, and references therein]. Inhaled nanoparticles may penetrate the alveolar-capillary barrier between the respiratory and circulatory system, and thus be translocated from the lungs [2, 3, 30-42, and references therein]. When the nanoparticles translocate to the circulatory system, other organs may also be affected $[1-3,15$, 16, 30-32, 39-42]. Translocation from the lungs may vary considerably between nanoparticles Kreyling et al. [42] studied Ir nanoparticles with 15 and $80 \mathrm{~nm}$ diameters and found that translocation rates from the lungs to blood were in the order of $1-2 \%$, with a relatively lower rate for the larger nanoparticles. In a study with nanoparticles containing $\mathrm{CdSe}, \mathrm{ZnS}$, silica, $\mathrm{CdTe}$, and $\mathrm{ZnS}$ with a variety of organic coatings, Choi et al. [39] found that particles with a hydrodynamic diameter $<34 \mathrm{~nm}$ and a noncationic surface charge migrated rapidly from the lung to lymph nodes. When such nanoparticles had hydrodynamic diameter of $6 \mathrm{~nm}$, they migrated rapidly from the lungs to the bloodstream [39].

There is evidence that some inhaled persistent inorganic nanoparticles may also be translocated from the nasal area to the central nervous system via the olfactory nerve and bulb, thus posing a hazard to the central nervous system, including enhanced inflammation, apoptosis and changes of neurotransmitter levels, which in turn may affect neurotransmission and behavior [2, 3, 34, and references therein].

Distribution of nanoparticles from the bloodstream among the organs can be size-dependent [15, 33, 34]. Deposition may occur in the cardiovascular system, liver, brain, testis, spleen, stomach, and kidney [1-3, 15, 34-38, and references therein]. This in turn may lead to apoptosis of cells, inflammation, changes in immune responses and, in the case of $\mathrm{Cu}$ and $\mathrm{Mn}$ nanoparticles and exposure of the brain, to changes in neurotransmitter levels [1-3, 34, 38, and references therein]. Also there may be penetration of the placenta, potentially leading to pregnancy complications and developmental toxicity [e.g., 32, 35, 40, and references therein].

Apart from the effects of nanoparticles translocated from the respiratory system, negative effects of inhaled 
nanoparticles may also be associated with metabolic stressors and platelet-leukocyte aggregates which originate in inflammatory lung disease [43-45]. Metabolic stressors include inflammatory cytokines and oxidized biomolecules [43]. These stressors may trigger chronic inflammation in organs, and may lead to cardiovascular disease [43]. Also there is the possibility that metabolic stressors negatively affect development of the fetus [45]. Platelet-leukocyte aggregates have been linked to the progression of arteriosclerosis [44]. Also, there is the hypothesis that nanoparticles deposited in the respiratory system might alter the activity of the autonomous nervous system thereby, e.g., initiating cardiac arrhythmias [46].

Overall, exposure of the lungs to persistent inorganic and carbon nanoparticles has been linked with an increased risk of cardiovascular disease, reflected in cardiac dysfunction linked to protein phosphorylation, to myocardial infarction, progression of arthrosclerosis, augmented ischemia-reperfusion injury, increased thrombosis risk, arrhythmias and altered heart rate variability and to altered vascular tone and disruption of microvascular reactivity [1-3, 34, 46-51, and references therein]. In the case of exposure of the lungs to persistent inorganic and carbon nanoparticles, there is a potential for inflammation and dysfunction of other organs than the cardiovascular system, including liver, kidney, blood-brain barrier, brain, and spleen $[1-3,15,37,47,48$, 52, 53, and references therein]. Changes of immune responses (immunomodulation) not involving inflammation might also result [54-58]. It has been hypothesized that the latter changes might be linked to a higher risk of autoimmune, allergic and neoplastic disease [59]. In the case of high internal doses of Gd nanoparticles, skin thickening and fibrosis may occur in persons with severe renal dysfunction [18, and references therein].

As persistent nanoparticles tend to form assemblages in air, besides individual nanoparticles, aggregates and agglomerates may be inhaled $[8,14,30]$. Aggregates are characterized by relatively weak inter-particle interactions by van der Waals forces. Aggregates are characterized by relatively strong inter-particle bonds. In the respiratory system and elsewhere in the human body both assembly and disassembly (e.g., aggregation and de-aggregation) of assemblages containing nanoparticles are in principle possible [30]. Thus, it is important to know whether the hazards of agglomerates and aggregates of nanoparticles are different from those of individual nanoparticles. Limited research is available to answer this question. Borm et al. [30] reviewed the then available research about the effects of assemblages in 2006 and felt that there is no significant difference in toxicity of inhaled single nanoparticles and of assemblages of these nanoparticles, as assemblages retained the greater surface area of individual nanoparticles. In principle, however, aggregates and agglomerates may be different from monodisperse nanoparticles as they may differ as aerodynamic properties affecting penetration in the lungs, as to persistence in the lungs, translocation from the lungs, fate after this translocation and cytotoxicity. Some of these aspects relevant to hazard have been studied for some nanoparticles. There is some evidence that the pulmonary hazard of single-walled carbon nanotubes might be increased by the formation of nanotube assemblages in the lungs [60]. Kreyling et al. [61] found that the translocation from the rat lung to the circulatory system and other organs of assemblages of Ir (2-4 nm) and C (5-10 nm) nanoparticles was reduced if compared with individual (monodisperse) Ir and $\mathrm{C}$ nanoparticles. Albanese and Chan [62] studying the uptake of monodisperse and assemblage of $\mathrm{Au}$ nanoparticles by mammalian cells, found the uptake to be dependent on cell type with aggregate uptakes of assemblages ranging from $25 \%$ lower to a twofold increase if compared with monodisperse nanoparticles. Drescher et al. [63], using a eukaryotic cell model, saw a decrease of toxicity of amorphous $\mathrm{SiO}_{2}$ nanoparticles in case of agglomeration. However, in these experiments the addition of serum may be a confounding factor [64]. Another study regarding the cytoxicity of monodisperse amorphous $\mathrm{SiO}_{2}$ nanoparticles and assemblages thereof found no effect of aggregation and suggested as cause that the availability of nanoparticle surface area remained unaffected by the formation of assemblages [64]. Agglomerates of persistent nanoparticles with other substances may strongly impact hazard [29, 64 66]. For instance, agglomeration of carbon black nanoparticles with a variety of proteins may be highly conducive to the translocation of carbon black nanoparticles from the lungs to the bloodstream and to deposition in other organs [66].

All in all, the extent to which surface area of single nanoparticles remains available for reactivity when forming assemblages may be an important determinant of hazard.

Hazard may vary much between primary nanoparticles [e.g., 1-3, 67, 68, and references therein]. For instance long carbon nanotubes appear to be much more hazardous than $\mathrm{C}_{60}$ fullerenes [68]. This has implications for human health risk following inhalation.

In the following, determinants of hazard and risk of primary persistent engineered inorganic and carbon nanoparticles to human health following inhalation, as they appear to emerge from available research, are discussed.

A determinant of the inhalation risk of persistent nanoparticles found in many, though not in all, studies is the number of particles [1-3, 67, and references therein]. A likely explanation for this phenomenon is the following: nanoparticles may be cleared from the lungs by macrophages. However, when the number of inhaled 
nanoparticles exceeds the clean-up capacity of macrophages, nanoparticles will not be cleared away and may become hazardous [68]. Such particles may affect lung tissue or, as pointed out above, other organs.

A determinant of inhalation hazard is particle size and size distribution [1-3, 6, 42, 69, 70]. Size may affect physico-chemical properties of inorganic particles and is also a determinant of penetration of the lungs, uptake by cells and intracellular interactions leading to cytotoxicity $[1-3,6,42,69,70]$. In part the impact of nanoparticle size on hazard is linked to the consequences of size for surface area. For granular nanoparticles the surface area can easily be calculated when the particle diameter is known $[8$, and references therein]. Surface size as a determinant of hazard will be further discussed below.

Studies on inorganic nanoparticles have shown that efficiency of translocation from the lungs may be substantially larger for very small nanoparticles than for relatively large nanoparticles [42, 69]. On the other hand, spherical $\mathrm{TiO}_{2}$ nanoparticles $<5.5 \mathrm{~nm}$ can be rapidly cleared from circulating blood [70]. In the case of $\mathrm{Au}$ nanoparticles cytotoxicty has been found dependent on size. The cytotoxicity of $1.4 \mathrm{~nm}$ Au particles was sixfold higher than the cytotoxicity of $0.8,1.2$, and $1.8 \mathrm{~nm}$ [15]. Studying Ag nanoparticles of 10, 80, and $113 \mathrm{~nm}$, Park et al. [71] found in increase in cytotoxicity linked to a decrease in size, whereas $\mathrm{Li}$ et al. [72] reported an increase in cellular toxicity when the particle size of amorphous silica nanoparticle decreased from 68 to $19 \mathrm{~nm}$.

Size-related differences in translocation from lungs to blood circulation, clearance from blood circulation, cell penetration and intracellular interactions may give rise to non-linear relations between size and hazard.

Surface characteristics can be categorized as a further determinant of hazard. They are important for reactivity (oxidation by generated reactive oxygen species), the release of hazardous substances and nanoparticle uptake by cells [1-3, 73-83]. A number of surface characteristics have been identified as relevant to the inhalation hazard of nanoparticles. These include surface area of inhaled particles, surface charge, hydrophilicity and surface chemistry, including catalytic activity and solubility of substances present in the nanoparticle $[1-3,39,65,74-86]$. For instance, as pointed out before, Choi et al. [39] found that noncationic nanoparticles $<34 \mathrm{~nm}$ were rapidly translocated from the lungs, whereas cationic nanoparticles of a similar size were not. The generation of $\mathrm{Ag}$ ions by silver nanoparticles [82] and the release of ionic $\mathrm{Cd}$ and Se from CdSe quantumdots $[16,36,84,85]$ are determinants of nanoparticle hazard. Metal solubility has been found a determinant in cytotoxicity of metal oxide and metal hydroxide nanoparticles $[19,86]$. Releases of ions from nanoparticles tend to increase when nanoparticles become smaller [6, 16, and references therein]. The abundance or density and distribution of silanols at the surface of $\mathrm{SiO}_{2}$ nanoparticles have been suggested as major determinants of nanosilica hazard [81].

Surface area has been suggested as an overall metric for nanoparticle hazard [65, 87-89] though it is highly doubtful whether this metric would, e.g., still reflect hazard at $\mathrm{TiO}_{2}$ nanoparticle sizes $<10 \mathrm{~nm}$ [6]. Surface reactivity has also been suggested as overall metric of nanoparticle hazard, in line with the generation of reactive oxygen species being a major molecular mechanism underlying hazard [ $1-3$, and references therein].

Finally, shape, structure and rigidity may be relevant to the hazards of persistent nanoparticles $[1-3,5,6,68,84$, 90-92]. For instance, very long $\mathrm{C}$ nanotubes (length $>5 \mu \mathrm{m}$ ) have a number of characteristics which are similar to those of asbestos, whereas relatively short $\mathrm{C}$ nanotubes do not share these characteristics [68]. Similarly, nanobelts of $\mathrm{TiO}_{2}$ longer than $15 \mu \mathrm{m}$ have been shown to be highly toxic if compared with $\mathrm{TiO}_{2}$ nanobelts shorter than $5 \mu \mathrm{m}$ [91]. A possible explanation for the relatively large hazard of very long nanoparticles is: frustrated phagocytosis, the inability of macrophages to clear away very long nanotubes [68]. Frustrated phagocytosis may be relevant too to the hazard of graphene nanoplatelets [92].

"Spikiness" may also matter. Nanoparticles with thin protrusions ("urchins") are preferentially taken up by a specific type of brain cells: microglia [55].

The importance of structure is illustrated by evidence that crystalline silica nanoparticles are more hazardous to lung tissue than amorphous silica nanoparticles [81].

Ceteris paribus, rigid nanoparticles may be more hazardous than their flexible counterparts. This has been shown for nanoparticulate dendrimers [90], and may also apply to, e.g., carbon nanotubes and nanofibers.

\section{Molecular mechanisms underlying the cytotoxicity of persistent inorganic and carbon nanoparticles}

A major molecular mechanism underlying inhalation hazard of persistent nanoparticles at the cellular level appears to be the generation of reactive oxygen species, such as superoxides, hydroxyl radicals, singlet oxygen, and hydrogen peroxide $[1-3,12,14,74,76,78-80,83,93-96$, and references therein]. The exposure of cells to reactive oxygen species in turn may lead to mutagenesis, genome instability, tumor formation, apoptosis, necrosis, and inflammation $[1-3,78-80,83,93-96$, and references therein]. There are however, also other potential molecular mechanisms underlying hazard. The contribution of released hazardous substances to nanoparticle toxicity has already been mentioned. An example of another 
mechanism which may underlie nanoparticle hazard is the nanoparticle-induced change in structure of functional proteins, negatively affecting protein functionality, such as enzymatic activity [97, 98]. Biological effects of $\mathrm{Au}, \mathrm{Pt}$, and $\mathrm{Ag}$ nanoparticles have for instance been linked to interactions with specific proteins, negatively affecting their activity [99, and references therein]. There is also some evidence that cytotoxicity of $\mathrm{TiO}_{2}$ may be partly linked to the adsorption of proteins and $\mathrm{Ca}^{2+}[100]$. Another possibility which has been raised is that persistent nanoparticles may negatively affect DNA by their impact on molecules such as ATP [101] or, in the case of fullerenols [102], $1.4 \mathrm{~nm} \mathrm{Au}$ particles [15], and $4.5 \mathrm{~nm} \mathrm{CdSe}$ particles [103], by direct interaction with DNA. Direct interactions between nanoparticles of specific sizes and DNA may give rise to nonlinear relations between nanoparticle size and hazard. Interactions between single-walled nanotubes and mitotic spindles have been noted too [34, and references therein]. Physical disruption of biological structure has been suggested to contribute to the hazard of nanoclay [104].

The molecular mechanisms underlying the cytotoxicity of inhaled persistent inorganic and carbon nanoparticles are also thought to be relevant to the hazards linked to other types of exposure, such as ingestion of such nanoparticles and dermal exposure.

It might furthermore be noted that there are differences in individual responses to inhaled inorganic and carbon nanoparticles, which may impact hazard and risk. For instance there are large differences between individuals in protection against, and return to homeostasis after, oxidative stress caused by reactive oxygen species [74]. Also, it has been noted that there are age-related responses to the inhalation of amorphous $\mathrm{SiO}_{2}$ nanoparticles [105]. This research suggests that the hazard of such nanoparticles may be relatively low at medium adult age and relatively large for old people [105]. Children and diabetics are expected to be relatively vulnerable to airborne persistent nanoparticles $[46,106]$. Nanoparticle cytotoxicity can be cell-type dependent and between-nanoparticle differences in target cell-type may also affect hazard $[107,108]$.

\section{Health hazards linked to ingestion of persistent inorganic and carbon nanoparticles by humans}

Ingestion of persistent nanoparticles by humans may be linked to the consumption of products to which nanoparticles have been added. For instance, nanoparticulate inorganic glidants (or anti-caking agents), such as nano$\mathrm{SiO}_{2}$, are applied in foodstuffs and pharmaceuticals which are to be ingested. Ag nanoparticles have a longstanding application as colloidal silver, which was and is used as a medicine. Also, some personal care products containing nanoparticles (e.g., lip gloss containing $\mathrm{TiO}_{2}$-based nanoparticulate sunscreens) may be ingested [109]. Furthermore, nanoparticles emitted into the environment may end up in food.

The study of human health hazards following from ingestion of persistent nanoparticles is so far very limited. Large exposures of humans to ingested colloidal silver are linked to silver deposits in mucous membranes and under the skin (argyria), to dysfunctioning of the central nervous system, liver, and kidneys and to severe immunological responses [110, 111]. Oral exposure of rats to silver nanoparticles has been found to give rise to relatively high concentrations in the intestines, spleen, liver and kidneys, with the preferential organ for deposition being sizedependent $[112,113]$.

There is some evidence for intestinal immunomodulation and inflammation by $\mathrm{TiO}_{2}$ nanoparticles, also in the case of sizes in excess of $100 \mathrm{~nm}$ [11, and references therein]. Dependent on size and character of the particle surface, translocation of nanoparticles from the intestines to the cardiovascular system is a possibility $[41,114,115]$. For instance, $\mathrm{C}_{60}$ nanoparticles (fullerenes) present in the milk of lactating rats were found to lead to systemic exposure of offspring to $\mathrm{C}_{60}$ [41].

Presence of nanoparticles in the blood circulation may lead to deposits in organs, possibly linked to an inflammation hazard an immunomodulation. The cardiovascular system may be negatively impacted by ingested persistent iron oxide nanoparticles [80]. In the case of amorphous $\mathrm{SiO}_{2}$ nanoparticles, ingestion of large amounts has been associated with negative impacts on liver functioning in mice [116].

Uptake of dissolved ions from the intestines may occur in the case of $\mathrm{Ag}, \mathrm{ZnO}$, and $\mathrm{Cu}$ nanoparticles and $\mathrm{CdSe}$ quantum dots $[6,16$, and references therein]. One would expect that release of ions from $\mathrm{Ag}, \mathrm{ZnO}, \mathrm{Cu}$, and $\mathrm{CdSe}$ nanoparticles may increase when the nanoparticles become smaller [6, 16, and references therein].

\section{Human health hazards following from dermal exposure to persistent inorganic and carbon nanoparticles}

In the case of dermal exposure to inorganic and $\mathrm{C}$ nanoparticles, there is a possibility that these nanoparticles might breach the barrier of the stratum corneum and enter the epidermis, and possibly the dermis. If so, there is potential for interaction with antigen presenting cells and immunomodulation [117] and for generation of reactive oxygen species, which might, e.g., lead to inflammation or carcinogenic effects [118]. There is also the possibility that 
reactive oxygen species generated at the surface of the skin, or reaction products thereof, are able to penetrate into the epidermis [109]. There is, as yet, no research regarding the latter possibility. Also potentially, nanoparticles might be subject to transdermal translocation.

Substantial research has been done regarding hazards following from dermal exposure to coated $\mathrm{TiO}_{2}$ nanoparticles which show at least some photocatalytic activity [7, 109, 118-120]. This photocatalytic activity gives rise to the generation of reactive oxygen species. As to photocatalytic activity the anatase variety of $\mathrm{TiO}_{2}$ is more active than the rutile variety [7]. The hazard of $\mathrm{TiO}_{2}$ nanoparticles to the skin is at least partly dependent on penetration of nanoparticles and/or reactive oxygen species, through the stratum corneum, into the living part of the skin [109, 118, 119, and references therein]. Though many studies with intact skins did not find penetration of the stratum corneum by $\mathrm{TiO}_{2}$ nanoparticles, some research suggests that breaching of the stratum corneum by $\mathrm{TiO}_{2}$ nanoparticles might occur in the case of dermabrasion and sunburn and might be facilitated by flexing of the skin and in the case that nanoparticles remain on the skin for a long time [109, 118,119 , and references therein]. Oily vehicles for dermal exposure to nano $\mathrm{TiO}_{2}$ may be more conducive to skin penetration than aqueous vehicles [34, and references therein]. The size of $\mathrm{TiO}_{2}$ nanoparticles may be important for hazard. Barnard [7] has suggested that the per particle hazard of $\mathrm{TiO}_{2}$ nanoparticles linked to the generation of reactive oxygen species under irradiation by sunlight has a maximum at $\sim 33 \mathrm{~nm}$. It may well be that smaller nanoparticles are more likely to breach the barrier of the stratum corneum than larger nanoparticles [120]. Following breaching of the stratum corneum, effects may be based on interaction with antigen presenting cells [117] and the molecular mechanisms discussed before, such as the generation of reactive oxygen species and interaction with cellular components such as proteins [1-3, 96-99, and references therein]. Research so far has not provided evidence of transdermal penetration of $\mathrm{TiO}_{2}$ nanoparticles $[119,120]$.

In the case of dermal exposure to coated $\mathrm{ZnO}$ nanoparticles, which show at least some photocatalytic activity, one study has reported breaching of the stratum corneum of sunburned skins [119]. This might give rise to effects similar to those of $\mathrm{TiO}_{2}$ nanoparticles. Some penetration of $\mathrm{Zn}$ through the human skin following dermal exposure to $\mathrm{ZnO}$ nanoparticles has been found, but it is so far unclear whether nanoparticles or $\mathrm{Zn}$ ions penetrate [109, 121, and references therein].

Ryman-Rasmussen et al. [122] found that nano-sized quantum dots with a variety of physicochemical properties might be able to penetrate the stratum corneum of the porcine skin in the absence of abrasion or mechanical stress. Quantum dots were found in the dermis and epidermis [122]. Quantum dots with an anionic coating penetrated much slower than those with cationic or neutral coatings [123]. Penetration of the skin by quantum dots might lead to systemic exposure to Cd [16]. Damaged (e.g., abraded) skins, ultra violet irradiation and increased physical load might increase the hazard of skin exposure to CdSe quantum dots [123-126]. Hoshino et al. [127] did show that the cytotoxicity of coated quantum dots increased to the extent that the surface charge was more positive.

Breaching of the stratum corneum of the intact and damaged human skin by $\mathrm{Ag}$ nanoparticles coated with polyvinylpyrrolidone has been suggested by Larese et al. [128]. Dermal exposure to Ag nanoparticles has also been associated with reduced epidermal keratinocyte viability [129].

A study on topical applications of amorphous $70 \mathrm{~nm}$ $\mathrm{SiO}_{2}$ particles on the mouse skin suggested that there was substantial translocation into the bloodstream, leading to systemic exposure [130], but it should be noted that oral uptake was not excluded in this study. Rouse et al. [131] found that amino acid-derivatized peptide fullerenes are able to penetrate the porcine skin, possibly giving rise to systemic exposure. Such penetration was facilitated by flexing the skin [131]. Xia et al. [132], also working with porcine skins, found that exposure to pristine fullerenes $\left(\mathrm{C}_{60}\right)$ in organic industrial solvents may lead to breaching the stratum corneum. Skin and systemic effects of $\mathrm{SiO}_{2}$ and fullerene particles may be based on the molecular mechanisms outlined previously, such as the generation of reactive oxygen species and the interaction with cellular components.

Murray et al. [133] concluded that unpurified singlewalled carbon nanotubes may give rise to skin inflammation, presumably linked to the generation of reactive oxygen species which is favored by the presence of metal residues in unpurified nanotubes.

From the studies regarding skin exposure to nanoparticles [7, 16, 109, 117-133] several likely determinants of hazard emerge. These include size, chemical composition, surface characteristics, such as surface coating and surface charge, and crystalline structure. Skin characteristics are also important. Abrasion and sunburn and flexing of the skin may be conducive to breaching of the stratum corneum by nanoparticles.

It has further been hypothesized that skin diseases such as dermatitis and psoriasis might facilitate the penetration of the stratum corneum by nanoparticles [134]. Robustness of the tumor suppressor p53 pathway in skin cells may be a significant determinant in the ability of $\mathrm{ZnO}$ nanoparticles to protect against, or accelerate, skin cancer [135]. 


\section{Human health hazards from exposure of the eye to nanoparticles}

The potential hazards due to exposure of the eye to persistent inorganic and carbon nanoparticles have been largely neglected so far [136]. However, there is some evidence that $\mathrm{Cd}$ originating in exposure of the eye to $\mathrm{CdSe} / \mathrm{ZnS}$ quantum dots may lead to cytotoxicity, whereas a particulate effect of such quantum dots on the eye has not been excluded [136]. Ema et al. [137] found that multiwalled carbon nanotubes may be weak eye irritants.

\section{Indirect effects on human health}

There may be indirect human health hazards from the use of engineered nanoparticles. For instance, widespread use of $\mathrm{Ag}$ nanoparticles may lead to increased resistance of pathogens to $\mathrm{Ag}$, which is an essential drug in case of protecting burns against infections [138, 139] and might lead to reduced effectiveness of waste water treatment, which in turn might give rise to increased levels of hazardous substances in surface waters [140].

\section{Emerging workplace standards for nanoparticles}

Scientific research showing that the hazards of nanoparticles can be different from larger particles has led to interest in workplaces which are considered a likely source of substantial exposure to engineered nanoparticles $[8,20$, 141 , and references therein]. A case of workplace exposure to amorphous silica nanoparticles which may have contributed to occupational pulmonary disease has been reported [142], though it should be noted that in this case there was also exposure to other hazardous substances.

The focus on workplace exposure to nanoparticles is gradually leading to the emergence of specific workplace standards for such particles $[8,10]$.

There are different strategies for the derivation of such workplace standards.

In the United States NIOSH has proposed a standard for $\mathrm{TiO}_{2}$ nanoparticles in workplace air on the basis of available toxicity data, specifically data linking tumors to exposure [143]. This proposed standard is $0.3 \mathrm{mg} \mathrm{m}^{-3}$, as time-weighted average for up to $10 \mathrm{~h}$ per day during a $40 \mathrm{~h}$ working week. This is a factor 8 stricter than the US standard for fine $\mathrm{TiO}_{2}$ particles [143].

NIOSH has also published a draft standard for exposure to carbon nanotubes and carbon nanofibers-based on available toxicity data [144]. In this case hazard would justify an $8 \mathrm{~h}$ time-weighted average between 0.2 and $2 \mu \mathrm{g} \mathrm{m}^{-3}$ air, but due to a higher upper limit of detection $7 \mu \mathrm{g} \mathrm{m}^{-3}$ was proposed.

Other strategies start from the assumption that conventional recommended health-based occupational exposure limits are as yet often impossible, as sufficient scientific research is unavailable and may remain so for a considerable time. Invoking the precautionary principle, which allows for government interventions in the absence of conclusive scientific proof, precautionary standards, provisional nano-reference values or benchmark levels have been proposed.

Table 1 gives as an example provisional nano-reference values for exposure to (bio) persistent nanoparticles in the workplace as they have been accepted in 2011 by representatives of trade unions and employers' organizations in the Netherlands [8]. These standards are linked to three determinants of risk discussed before: number, rigidity and

Table 1 Precautionary standards or provisional nano-reference values for nanoparticles in workplace air (as accepted by representatives of trade unions and employers' organizations in the Netherlands, 2011), based on a proposal of the Institut für Arbeitsschutz der Deutschen Gesetzlichen Unfallversicherung [8]

\begin{tabular}{|c|c|c|c|}
\hline Description of nanoparticle type & Density & $\begin{array}{l}\text { Precautionary } \\
\text { workplace standard }(8 \mathrm{~h} \\
\text { time-weighted average })\end{array}$ & Examples of nanoparticles covered by the standard \\
\hline $\begin{array}{l}\text { Rigid, biopersistent nanofibers and } \\
\text { nanotubes for which effects } \\
\text { similar to those of asbestos are } \\
\text { not excluded }\end{array}$ & - & 0.01 particle $/ \mathrm{cm}^{3}$ & $\begin{array}{l}\text { Single-walled or multiwalled } \mathrm{C} \text { nanotubes or metal } \\
\text { oxide nanofibers for which asbestos-like effects } \\
\text { are not excluded }\end{array}$ \\
\hline $\begin{array}{l}\text { Biopersistent granular } \\
\text { nanomaterial in the } 1-100 \mathrm{~nm} \\
\text { range }\end{array}$ & $>6000 \mathrm{~kg} / \mathrm{m}^{3}$ & 20000 particles $/ \mathrm{cm}^{3}$ & $\mathrm{CeO}_{2}, \mathrm{CoO}, \mathrm{Fe}, \mathrm{FeO}, \mathrm{La}, \mathrm{Pb}, \mathrm{Sb}_{2} \mathrm{O}_{5}, \mathrm{SnO}_{2}, \mathrm{Ag}, \mathrm{Au}$ \\
\hline $\begin{array}{l}\text { Biopersistent granular } \\
\text { nanomaterial in the } 1-100 \mathrm{~nm} \\
\text { range }\end{array}$ & $<6000 \mathrm{~kg} / \mathrm{m}^{3}$ & 40000 particles $/ \mathrm{cm}^{3}$ & $\begin{array}{l}\mathrm{Al}_{2} \mathrm{O}_{3}, \mathrm{SiO}_{2}, \mathrm{TiN}, \mathrm{TiO}_{2}, \mathrm{ZnO} \text {, nanoclay, carbon } \\
\text { black, fullerenes, } \mathrm{C} \text { dendrimers, nanotubes and } \\
\text { nanofibers for which asbestos-like effects are } \\
\text { excluded }\end{array}$ \\
\hline
\end{tabular}


shape. When the standards presented in Table 1 are exceeded, according to the representatives of trade unions and employers' organizations, the source of the nanoparticle emission should be identified, and measures should be taken to reduce the emission.

Another approach to standard setting has been proposed by Pauluhn [145]. This is a generic mass-based approach based on the assumption that the particle displacement volume corresponding with preventing an overload of nanoparticles, as determined in studies with rats, should be the basis of standard setting. This way of standard setting leads, when a conversion is made to particle numbers, to much more lenient standards than those presented in Table 1 [8]. Also the standard for carbon nanotubes and carbon nanofibers following from Pauluhn's proposal would be about a factor 7 higher than the draft standard proposed by NIOSH [144]. A problem with this proposal of Pauluhn [145] is the uncertainty about the correctness of models used to extrapolate from the overload as determined in rats to human health risk [2, 146, and references therein].

A third approach to standard setting has been proposed by the British Standards Institute (BSI) [147]. This approach is based on scaling from current health-based standards for large particles. For instance, for insoluble nanomaterials BSI suggests a benchmark value of $0.066 \times$ the current workplace exposure limit for particles in general. For nanoparticles to which applies that larger particles are classified as carcinogenic, mutagenic, asthmagenic or a reproductive toxin, the proposed standard is $0.1 \times$ the current workplace exposure limit for larger particles. The values in Table 1 turn out to be often stricter than the values based on the BSI approach, when a conversion is made to particle numbers [8, 10].

Still another approach has been suggested by Hesterberg et al. [148]. They reviewed the studies in which human volunteers are exposed to diesel exhaust particles, found a no adverse effect level between about 30000 and 50000 particles $/ \mathrm{cm}^{3}$ and suggest that this may be used as a reference value for estimating potential human health hazards of nanoparticles. This approach would lead to standards roughly similar to the standards for granular nanomaterials in Table 1.

Remarkably, none of the proposed standards are directly based on surface area or surface reactivity (the generation of reactive oxygen species), which as previously discussed have been proposed as metrics for nanoparticle hazard [e.g., 1-3, 65, 87-89].

Table 2 Human health hazard and risk reduction options in case of exposure to inorganic and carbon nanoparticles [8, 10, 11, 65, 147, 150-156, and references therein]

\begin{tabular}{ll}
\hline Hazard and risk reduction option & Example(s)
\end{tabular}

\section{Elimination/substitution}

Replacement by less hazardous substances

Restricting nanoparticle use to essential uses

Suppression of major determinants of hazard, reducing "intrinsic" nanoparticle hazard

Optimizing nanoparticle choice
Substitution of nanoparticulate glidants by stearates; substituting $\mathrm{Cr}$ and $\mathrm{Ni}$ by $\mathrm{Fe}$ in $\mathrm{C}$-nanotube production, elimination of metal catalysts in $\mathrm{C}$-nanotube production; substituting anatase by rutile in sunscreens

Restriction of $\mathrm{Ag}$ nanoparticles to a limited number of medical applications (treatment of burns, prostheses)

Suppression of generation of reactive oxygen species by coating or doping; reducing the presence of metal contamination in $\mathrm{C}$ nanotubes; increasing solubility of fullerenes

Reducing hazard by judicious choice of size and shape (while maintaining function)

Engineering controls reducing the release of nanoparticles, including enclosure

Increasing yields of nanoparticles in conformity with product specifications, to reduce waste handling hazards

Well-contained in situ production of nanoparticles on/in material used for coating or embedding \& well-contained transport of nanoparticles

Design to reduce nanoparticle release

Immobilization of nanoparticles on substrates

Wet chemistry in nanoparticle production

Use of glove boxes and hoods

Use of local ventilation and high efficiency particulate (HEPA) filters
Can be applied to many nanoparticle production processes

Production of self-cleaning glass

Catalytic converters in motorcars

Application of nano- $\mathrm{TiO}_{2}$ for degradation of hazardous substances

Can be applied to, e.g., the generation of $\mathrm{Al}_{2} \mathrm{O}_{3}$ nanoparticles

Laboratory scale work with nanoparticles

Near vessels mixing nanoparticulate materials, near vapor deposition reactor during clean out; filtering exhausts containing nanoparticles 
Remarkably also, there is as yet no proposal for an air quality standard regarding nanoparticles in outdoor air [149]. This is all the more remarkable because children are more vulnerable than adult workers in case of a specified particle concentration of airborne persistent nanoparticles $[46,106]$.

\section{Hazard and risk reduction}

Risk reduction currently tends to focus primarily on hazard reduction as close to the source as possible with elimination, substitution and engineering controls reducing exposure having priority $[8,10,20,150-156]$. Options for elimination, substitution and engineering controls close to the (potential) source of nanoparticles, with examples thereof $[8,10,11,65,147,150-156$, and references therein], are summarized in Table 2.

As to the option of reducing "intrinsic" hazards of nanoparticles, while maintaining functionality, one may note that knowledge accumulated so far about the determinants of, and molecular mechanisms underlying human health hazards, may serve to reduce such hazards. For instance, in the case of amorphous silica cytotoxicity to phagocytic cells might be reduced by functionalization with amine- and carboxyl-terminal groups [154]. Ag nanoparticles have been coated by protective hydrocarbons to reduce hazard [34, and references therein]. Reduction of Ag toxicity by the use of proteins such as lactalbumin has also been proposed [110]. Whether these treatments of amorphous silica and $\mathrm{Ag}$ nanoparticles reduce human health hazards in practice, remains to be shown.

The finding that photocatalytic activity of nano- $\mathrm{TiO}_{2}$ in sunscreens may be a major determinant of health hazards has given rise to the suppression thereof by coatings. A variety of substances is in use as coating materials for $\mathrm{TiO}_{2}$ nanoparticles. These include organic $\mathrm{Si}$-compounds, organic $\mathrm{Ti}$ compounds, $\mathrm{SiO}_{2}$ and $\mathrm{Al}_{2} \mathrm{O}_{3}$ [109, 157-159]. Research into the actual reduction of photocatalytic activity by such coatings shows that in commercial sunscreens the suppression of photocatalytic activity is variable $[157,158]$.

It has been argued that the pulmonary toxicity of carbon nanotubes may be reduced by a coating with polystyrene [160], whereas cytotoxicity of carbon nanotubes can be reduced by coating with polyethylene glycol [161]. An amorphous silica coating of magnetic iron oxide nanoparticles was found to reduce cytotoxicity to human airway epithelial cells [162]. Whether these coatings of carbon nanotubes and iron oxide nanoparticles reduce hazards to human health in practice has so far not been determined.

To reduce the release of ionic $\mathrm{Cd}$ from $\mathrm{CdSe} / \mathrm{ZnS}$ quantum dots, thereby reducing intrinsic hazard, coating or capping with thiols has been introduced [16]. When cappings or coatings are applied, the persistence thereof is a matter of concern. In the case if capping $\mathrm{CdSe} / \mathrm{ZnS}$ nanodots with thiols, there is evidence for intracellular degradation and instability in water, whereas after release into the environment photochemical degradation may occur $[16,153]$.

Protective hydrocarbon coating for Ag nanoparticles was found to be subject to degradation in the cellular environment [34, and references therein]. There may also be intracellular degradation of protein coatings [83, and references therein]. In the case of coated $\mathrm{TiO}_{2}$ nanoparticles, concern has been expressed about the ability of especially coatings with organic compounds to remain persistent $[109,163$, and references therein].

In the context of reducing releases of nano- $\mathrm{TiO}_{2}$, while exploiting the photocatalytic properties thereof, by engineering controls, several options are available for hazard reduction [164]. To the extent that nano- $\mathrm{TiO}_{2}$ is intended for photocatalytic treatment of water, fixation of $\mathrm{TiO}_{2}$ on a non-degradable substrate is probably associated with a lower hazard than using nano- $\mathrm{TiO}_{2}$ in suspension [164]. Such non-degradable substrates tend to be mineral in character as carbonaceous or organic substrates may be degraded by photocatalytic activity [164]. Well-contained in situ production of nanoparticulate $\mathrm{TiO}_{2}$ to be fixed on, or embedded in substrates and the use of closed systems for nanoparticle production, transport, and processing are also preferred [11].

Similar options might be available for other nanoparticles. For instance, the inhalation hazard linked to the use of $\mathrm{CeO}_{2}$ nanoparticles in diesel fuel might be reduced by the use of substrate-embedded nanoparticles for exhaust treatment.

To the extent that wear and tear of substrates with embedded nanoparticles give rise to particle formation, design of nanocomposites may be such that preferentially large particles are generated. This option is illustrated by catalytic converters in motorcars which are designed in a way that relatively large particles containing nanoPt are emitted [11].

\section{Conclusion}

Persistent inorganic and carbon nanoparticles are increasingly engineered for applications and may also be present in conventional materials such as carbon black and talc. Furthermore, such nanoparticles may originate in conventional non-nanoparticulate materials by processes such as wear and tear. Persistent inorganic and carbon nanoparticles can 
be hazardous to humans. Relatively, much research regards the hazards of inhaled nanoparticles. These may give rise to respiratory disease and to negative effects on other organs, including the cardiovascular system. Determinants of hazard of inhaled nanoparticles are number, size and size distribution, surface characteristics, shape, structure and the formation of assemblages. These determinants should preferentially be considered in exposure metrics. A major molecular mechanism underlying the inhalation hazard of nanoparticles is the generation of reactive oxygen species, but other mechanisms such as interactions with proteins and DNA may also contribute. Health hazards may also be linked to ingestion of persistent inorganic and carbon nanoparticles, dermal exposure and exposure of the eye. Standards for workplace exposure to persistent inorganic and carbon are currently emerging and there are options for hazard reduction by elimination and substitution of hazardous nanoparticles and by engineering controls.

Acknowledgement The comments of three anonymous reviewers are gratefully acknowledged.

\section{References}

1. Fubini B, Ghiazza M, Fenoglio I (2010) Nanotoxicology 4:347

2. Maynard AD, Warheit DB, Philbert MA (2011) Toxicol Sci 120:S109

3. Oberdorster G (2010) J Intern Med 267:89

4. European Commission (2011) Off J Eur Un 275:38

5. Auffan M, Rose J, Bottero J, Lowry GV, Jolivert J, Wiesner MR (2009) Nat Nanotechnol 4:634

6. Jiang J, Oberdörster G, Elder A, Gelein R, Mercer P, Biswas P (2008) Nanotoxicology 2:33

7. Barnard AS (2010) Nat Nanotechnol 5:271

8. van Broekhuizen P, van Broekhuizen F, Cornelissen R, Reijnders L (2012) J Nanopart Res, submitted for publication

9. Reijnders L (2011) In: Nittal V et al (eds) Recent advances in elastomeric nanocomposites, advanced stuctured materials, vol 9. Springer, Berlin, p 179

10. van Broekhuizen P, van Broekhuizen F, Cornelissen R, Reijnders L (2011) J Nanopart Res 13:442

11. Reijnders L (2008) J Ind Ecology 12:297

12. Wohlleben W, Brill S, Meier MW, Mertler M, Cox G, Hirth S, von Vacano B, Strauss V, Treumann S, Wiench K, Ma-Hock L, Landsiedel R (2011) Small. doi: 10.1002/smll.201002054

13. Karlsson HL, Cronholm P, Gustafsson J, Möller L (2008) Chem Res Toxicol 21:1716

14. Stone V (2009) Engineered nanoparticles: review of health and environmental safely. Napier University, Edinburgh (UK)

15. Aillon KL, Xie Y, El-Gendy N, Berkland CJ, Forrest ML (2009) Adv Drug Deliv Rev 61:457

16. Rzigalinski BA, Stroble JS (2009) Toxicol Appl Pharmacol 238:280

17. Schrand AM, Rahman MA, Hussain SM, Schlager JJ, Smith DA, Syed AF (2010) WIRES Nanomed Nanobiotechnol 2:544

18. Sieber MA, Pietsch H, Walter J, Haider W, Frenzel T, Weinmann H (2008) Invest Radiol 43:65

19. Kang GS, Gillespie PA, Gunnison A, Rengifo H, Koberstein J, Chen L (2011) Inhal Toxicol 23:95
20. van Broekhuizen P, Reijnders L (2011) Risk Anal 31:1646

21. Scymczak W, Menzela N, Kecka L (2007) Aerosol Sci 38:520

22. Barthel M, Pedan V, Hahn O, Rothhardt M, Bresch H, Jann O, Seeger S (2011) Environ Sci Technol 45:7819

23. Beniwal R, Shivgotra VK (2009) Cardiovasc Toxicol 9:194

24. Xia Z, Kwon Y, Mehmood S, Downing C, Jurkschat K, Murray DW (2011) Nanomed Nanotechnol Biol Med 7:674

25. Baun A, Sorensen SN, Rasmussen RF, Hartmann NB, Koch CB (2008) Aquatic Toxicol 86:379

26. Aschberger K, Michelett C, Sokull-Klüttgen B, Christensen FM (2011) Environ Int 37:1143

27. Kahru A, Dubourguier H (2009) Toxicology 269:105

28. Turco RF, Bischoff M, Tong ZH, Nies L (2011) Curr Opin Biotechnol 22:1527

29. Menard A, Drobne D, Jemec A (2011) Environ Pollut 159:577

30. Borm PJ, Robbins D, Haubold S, Kuhlbush T, Fissan H, Donaldson K, Schins R, Stone V, Kreyling W, Lademann J, Krutman J, Warheit D, Oberdörster E (2006) Part Fibre Toxicol 3:11

31. Pacurai M, Castranova V, Vallyathan V (2010) J Toxicol Environ Health Part A 73:378

32. Yamashita K, Yoshioka Y, Higashisaka K, Mimura K, Morishita Y, Nozaki M et al (2011) Nat Nanotechnol 6:321

33. Hardas SS, Butterfield DA, Sultana R, Tseng MT, San M, Florence RL, Unrine JM, Graham UM, Wu P, Grulke EA, Yokel RA (2010) Toxicol Sci 116:562

34. Hubbs AF, Mercer RR, Benkovic SA, Harkema J, Sriram K, Schwengler-Berry D, Goravanahally MP, Nurkiewicz TR, Castranova V, Sargent LM (2011) Toxicol Pathol 39:301

35. Braydich-Stolle LK, Lucas B, Schrand A, Murdock RC, Lee T, Schlager JJ, Hussain SM, Hofmann M (2010) Toxicol Sci 116:577

36. Su Y, Peng F, Jang Z, Zhong Y, Lu Y, Jiang X, Huang Q, Fan C, Lee S, He Y (2011) Biomaterials 32:5855

37. Zhang L, Bai R, Liu Y, Meng L, Li B, Wang L, Xu L, le Guyader L, Chen C (2012) Nanotoxicology. doi:10:3109/ 17435390.2011.590906

38. Ngwa HA, Kanthasamy A, Gu Y, Fang N, Anantharam V, Kanthasamy (2011) Toxicol Appl Pharmacol 256:227

39. Choi HS, Ashitate Y, Lee JH, Kim SH, Matsui A, Insin N, Bawendi MG, Semmler-Behnke M, Frangioni JV, Tsuda A (2010) Nat Biotechnol 28:1300

40. Hougaard KS, Jackson P, Jensen KA, Sloth JJ, Löschner K, Larsen EH (2010) Part Fibre Toxicol 7:16

41. Sumner SCJ, Fennell TR, Snyder RW, Taylor GF, Lewin AH (2010) J Appl Toxicol 30:354

42. Kreyling WG, Semmler M, Erbe F, Mayer P, Takenaka S, Oberdörster G, Ziesenis A (2002) J Toxicol Environ Health A 65:1513

43. Gomez-Mejiba SE, Zhai Z, Akram H, Pye QN, Hensley K, Kurien BT, Scofield RH, Ramirez DC (2009) Mutat Res 674:62

44. Tabuchi A, Kuebler WM (2008) Vasc Pharmacol 49:141

45. Jackson P, Hougaard KS, Vogel U, Wu D, Casavant L, Williams A, Wade M, Yauk CL, Wallin H, Halappanavar S (2012) Mutat Res. doi:10.1016/j.mrgentox.2011.09.018

46. Rückerl R, Schneider A, Breitner S, Cyrys J, Peters A (2011) Inhal Toxicol 23:555

47. Nurkiewicz TR, Porter DW, Hubbs AF, Stone S, Chen BT, Frazer DG et al (2009) Toxicol Sci 110:191

48. Leblanc AJ, Moseley AM, Chen BT, Frazer S, Castranova V, Nurkiewicz TR (2010) Cardiovasc Toxicol 10:27

49. Vesterdal LK, Folkmann JK, Jacobsen NR, Sheytkhzade M, Wallin H, Loft S, Moller P (2010) Part Fibre Toxicol 7:33

50. Kan H, Wu Z, Young S, Chen T, Cumpston JL, Chen F, Kashon ML, Castranova V (2012) Nanotoxicology. doi:10.3109/17435390. 2011.011915 
51. Semberova J, De Paoli Lacerda SH, Simakova O, Holada K, Gelderman MP, Simak J (2009) Nano Lett 9:3312

52. Trickler WJ, Lantz SM, Murdock RC, Schrand AM, Robinson BL, Newport GD, Schlager JJ, Oldenburg SJ, Paule MG, Slikker W, Hussain SM, Ali SF (2010) Toxicol Sci 118:160

53. Simko M, Mattson M (2010) Part Fibre Toxicol 7:42

54. Palomäki J, Karisola P, Pylkkänen L, Savolainen K, Alenius H (2010) Toxicology 267:125

55. Albanese A, Syjes EA, Chan WCW (2010) ACS Nano 4:2490

56. Sperling RA, Casals E, Comenge J, Bastus NG, Puntes VF (2009) Curr Drug Metab 10:895

57. Villiers CL, Freitas H, Coudere R, Villiers M, Marche PN (2010) J Nanopart Res 12:55

58. Maurer Jones M, Lin Y, Haynes CL (2010) ACS Nano 4:3363

59. Chang C (2010) J Autoimmun 34:J234

60. Mutlu GM, Budinger GRS, Green AA, Urich D, Soberanes S, Chiarella SE, Alheid GF, McCrimmon DR, Szleifer I, Hersam MC (2010) Nano Lett 10:1664

61. Kreyling WG, Sammler-Behnke M, Seitz J, Scymczak W, Wenk A, Mayer P, Takenaka S, Oberdörster G (2009) Inhal Toxicol 21:55

62. Albanese A, Chan WCW (2011) ACS Nano 5:5478

63. Drescher D, Orts-Gil G, Laube G, Natte K, Veh RW, Österle W, Kneipp J (2011) Anal Bioanal Chem 400:1367

64. Rabolli V, Thomassen LCJ, Uwambayinema F, Martens JA, Lison D (2011) Toxicol Lett 206:197

65. Yokel RA, MacPhail RC (2011) J Occup Med Toxicol 6:7

66. Fertsch-Gapp S, Semmler-Behnke M, Wenk A, Kreyling WG (2011) Inhal Toxicol 23:468

67. Warheit DB (2010) Anal Bioanal Chem 3988:607

68. Borm P, Castranova V (2009) Part Fibre Toxicol 6:28

69. Semmler-Behnke M, Kreyling WG, Lipka J, Fertsch S, Wenk A, Takenaka S, Schmidt G, Brandau W (2008) Small 4:2108

70. Choi HS, Liu W, Liu F, Nasr K, Misra P, Bawendi MG, Frangioni JV (2010) Nat Nanotechnol 5:42

71. Park MVDZ, Neigh AM, Vermeulen JP, de la Fonteyne LJJ, Verharen HW, Briedé JJ, van Loveren H, de Jong WH (2011) Biomaterials 32:9810

72. Li Y, Sun L, Jin M, Du Z, Liu X, Guo C, Li J, Huang P, Sun Z (2011) Toxicol In Vitro 25:1343

73. Kayat J, Gajbhiye V, Tekade RK, Kumar N (2011) Nanomed Nanotechnol Biol Med 7:40

74. Ayres JG, Borm P, Cassee FR, Castranbova V, Donaldson K, Ghio A, Harrison RM, Hider R, Kelly F, Kooter IM (2008) Inhal Toxicol 20:75

75. Clift MJD, Rothen-Rutishauser B, Brown DM, Duffin R, Donaldson K, Proudfoot L, Guy K, Stone V (2008) Toxicol Appl Pharmacol 232:418

76. Limbach L, Wick P, Manser OP, Grass RN, Bruinink A, Stark WJ (2007) Environ Sci Technol 41:4158

77. Duffin R, Tran L, Brown D, Stone V, Donaldson K (2007) Inhal Toxicol 19:849

78. Koike E, Kobayashi T (2011) Chemosphere 65:946

79. Hussain S, Boland S, Baeza-Squiban A, Hamel R, Thomassen LCJ, Martens JA, Billon-Galland MA, Fleury-Feith J, Moisan F, Pairon J, Marano F (2009) Toxicology 260:142

80. Zhu M, Wang B, Wang Y, Yuan L, Wang H, Wang M, Ouyang H, Chai C, Feng W, Zhao Y (2011) Toxicol Lett 201:162

81. Napierska D, Thomassen LCJ, Lison D, Martens JA, Hoet PH (2010) Part Fibre Toxicol 7:39

82. Marambio-Jones C, Hoek EMV (2010) J Nanopart Res 12:1531

83. Soenen SJ, Rivera-Gil P, Montenegro J, Parak WJ, de Smedt SC, Braeckmans K (2011) Nano Today 6:446

84. Sayes CM, Reed KL, Warheit DB (2007) Toxicol Sci 97:163

85. Navarro DA, Banerjee S, Watson DF, Aga DS (2011) Environ Sci Technol 45:6343
86. Liu R, Rallo R, George S, Ji Z, Nair S, Nel AE, Cohen Y (2011) Small 8:1118

87. Oberdörster G, Stone V, Donaldson K (2007) Nanotoxicology 1:2

88. Paur H, Cassee DR, Teeguarden J, Fissan H, Diabate S, Aufderheide M, Kreyling WG, Häninen O, Kasper G, Riediker M, Rothen-Rutishauser B, Schmid O (2011) J Aerosol Sci 42:608

89. Sager TM, Castranova V (2009) Part Fibre Toxicol 6:15

90. Longmire MR, Ogawa M, Choyke PL, Kobayashi H (2011) Bioconjug Chem 22:993

91. Hamilton RF, Wu N, Porter D, Buformd M, Wolfarth M, Holian A (2009) Part Fibre Toxicol 6:35

92. Schinwald A, Murphy FA, Jones A, MacNee W, Donaldson K (2012) ACS Nano. doi: 101021/nn204229f

93. Srinivas A, Rao PJ, Selvam G, Murthy PB, Reddy PN (2011) Toxicol Lett 205:105

94. Li JJ, Lo S, Ng C, Gurung RL, Hartono D, Hande MP, Ong C, Bay B, Yung LL (2011) Biomaterials 32:5515

95. Orrenius S, Nicotera P, Zhivotovsky B (2011) Toxicol Sci 119:3

96. Xu Z, Chou L, Sun J (2012) J Appl Toxicol. doi:10.1002/ jat. 1710

97. Xu Z, Wang S, Go H (2010) J Hazard Mater 180:375

98. Gagner JE, Lopez MS, Dordick JS, Siegel RW (2011) Biomaterials 32:7241

99. Bhattacharya R, Mukherjee P (2008) Adv Drug Deliv Rev 60:1289

100. Horie M, Nishio K, Fujita K, Endoh S, Mayauchi A, Saito Y et al (2009) Chem Res Toxicol 22:543

101. Myllynen F (2009) Nat Nanotechnol 4:795

102. An H, Jin B (2011) Environ Sci Technol 45:6608

103. Mahtab R, Sealey SM, Hunyadi SE, Kinard B, Ray T, Murphy CJ (2007) J Inorg Biochem 101:559

104. Lordan S, Kennedy JE, Higginbotham CL (2011) J Appl Toxicol $31: 27$

105. Chen Z, Meng H, Xing G, Yuasn H, Zhao F, Liu R, Chang X, Gao X, Wang T, Jia G, Ye C, Chai Z, Zhao Y (2008) Environ Sci Technol 42:8985

106. Schüepp K, Sly PD (2012) Pediatr Respir Rev. doi: 10.1016/ j.prrv.2011.08.002

107. Sohaebuddin SK, Thevenot PT, Baker D, Eaton JW, Tang L (2010) Part Fibre Toxicol 7:22

108. Yu T, Malugin A, Ghandehari H (2011) ACD Nano 5:5717

109. Reijnders L (2011) Househ Pers Care Today 3L:44

110. Panyala NR, Pena-Mendez EM, Havel J (2008) J Appl Biomed 6:117

111. Zhang B, Luo Y, Wang Q (2011) Int J Antimicrob Agents 38:502

112. Loeschner K, Hadrup N, Qvortrup K, Larsen A, Gao X, Vogel U, Mortensen A, Lam HR, Larsen EH (2011) Part Fibre Toxicol 8:18

113. Lankveld DPK, Oomen AG, Krystek P, Neigh A, Troost-de Jong A, Noorlander CW, van Eijkeren JCH, Geertsma RE, de Jong WH (2010) Biomaterials 31:8350

114. Florence AT (2005) Drug Discov Today Technol 2:75

115. Powell JJ, Faria N, Thomas-McKay E, Pele LC (2010) J Autoimmunol 34:J226

116. So SJ, Jang IS, Han CS (2008) J Nanosci Nanotechnol 8:5367

117. Nestle DO, DiMeglio P, Quin JZ, Nickoloff BJ (2009) Nat Rev Immunol 9:679

118. Tran DT, Salon R (2011) Australas J Dermatol 52:1

119. Monteiro-Riviere NA, Wiench K, Landsiedel R, Schulte S, Inman AO, Riviere JE (2011) Toxicol Sci 123:264

120. Wiechers JW, Mussee N (2010) J Biomed Nanotechnol 6:408

121. Gulson B, McCall M, Korsch M, Gomez L, Casey P, Oytam Y, Taylor A, McCulloch M, Trotter J, Kinsley L, Greenoak G (2010) Toxicol Sci 118:140 
122. Ryman-Rasmussen JP, Riviere JE, Monteiro-Riviere NA (2006) Toxicol Sci 91:159

123. Romoser AA, Chen PL, Berg JM, Seabury C, Ivanov I, Cricitiello MF, Sayes CM (2011) Mol Immunol 48:1349

124. Zhang LW, Yu WW, Colvin VL, Monteiro-Riviere NA (2008) Toxicol Appl Pharmacol 228:200

125. Rouse JG, Haslauer CM, Loboa EG, Monteiro-Riviere NA (2008) Toxicol In Vitro 22:491

126. Mortensen LJ, Oberdörster G, Pentland AP, DeLouise LA (2008) Nano Lett 8:2779

127. Hoshino A, Fujioka K, Oku T, Suga M, Sasaki YF, Ohta T, Yasuhara M, Suzuki KM, Yamamoto K (2004) Nano Lett 4:2163

128. Larese DD, D'Agostin FD, Crosera M, Adami G, Renzi N, Bovenzi M, Maina G (2009) Toxicology 255:33

129. Samberg ME, Oldenburg SJ, Monteiro-Riviere NA (2010) Environ Health Perspect 118:407

130. Nabeshi H, Yoshikawa T, Matsuyama K, Nakazato Y, Matsuo K, Arimori A (2011) Biomaterials 32:2713

131. Rouse JG, Yang J, Ryman-Rasmussen JP, Barron AR, MonteiroReviere NA (2007) Nano Lett 7:155

132. Xia XR, Monteiro-Riviere NA, Riviere JE (2010) Toxicol Appl Pharmacol 242:29

133. Murray AR, Kison E, Leonard SS, Young SH, Kommineni C, Kagan VE, Castranova V, Shvedova AA (2009) Toxicology 257:161

134. Prow TW, Grice JE, Lin LL, Faye R, Butler M, Becker W, Wurm EMT, Yoong C, Robertson TA, Soyer HP, Roberts MS (2011) Adv Drug Deliv Rev 63:470

135. Ng KW, Khoo SPK, Hweng BC, Setawati MI, Tan EC, Zha X, Xiong S, Fang W, Leong DT, Loo JSC (2011) Biomaterials 32:8218

136. Yamamoto S, Manabe N, Fujioka K, Hishino A, Yamamoto K (2007) IEEE Trans Nanobioscience 6:94

137. Ema M, Matsuda A, Kobayashi N, Naya M, Nakanishi J (2011) Regul Toxicol Pharmacol 61:276

138. Silver S (2003) FEMS Microbiol Res 27:341

139. Silver S, Phung LT, Silver G (2006) J Ind Microbiol Biotechnol 33:627

140. Frakas J, Peter H, Chritian P, Urrea JAG, Hassellöv M, Tuoriniemi J, Gustafsson S, Olsson E, Hylland K, Thomas KV (2011) Environ Int 37:1057

141. Kuhlbusch TAJ, Asbach C, Fissan H, Göhler D, Stintz M (2011) Part Fibre Toxicol 8:22
142. Song Y, Li X, Wang L, Rojanaskul Y, Castranova V, Li H, Ma J (2011) Toxicol Pathol 39:841

143. NIOSH (2011) Curr Intell Bull 63:1

144. NIOSH (2010) Curr Intell Bull 161-A:1-149

145. Pauluhn J (2011) Toxicology 279:176

146. Kuempel ED, Tran CL, Castranova V, Bailer AJ (2006) Inhal Toxicol 18:717

147. British Standards Institute (2007) Guide to safe handling and disposal of manufactured nanomaterials. Nanotechnologies Part 2. PD 6699-2-2007. BSI, London

148. Hesterberg TW, Long CM, Lapin CA, Hamade AK, Valberg PA (2010) Inhal Toxicol 23:679

149. N. Künzli (2011) Eur Heart J. doi: 10.1093/eurhartj/ehr200

150. Ayotte PR (2011) J Phys Conf Ser 304:012071

151. Sayes CM, Fortner JD, Guo W, Lyon D, Boyd AM, Ausman KD, Tao YJ, Sitharaman B, Wilson LJ, Hughes JB, West JL, Colvin VL (2004) Nano Lett 4:1881

152. Woskie S (2010) Nanomedicine Nanobiotechnol 2:685

153. Pace HE, Lesher EK, Ranville JF (2010) Environ Toxicol Chem 29:1338

154. Magulin A, Herd H, Ghandehari H (2011) J Nanopart Res. doi:10.1007/s11051-011-0524-7

155. Maynard AS (2007) Ann Occup Hyg 51:1

156. Schulte PA, Geraci CL, Zumwalde R, Hoover M, Kuempel E (2008) J Occup Environ Hyg 5:239

157. Carlottin ME, Ugazio E, Sapino S, Fonoglio I, Greco G, Fubini B (2009) Free Radic Res 43:312

158. Barker PJ, Branch A (2008) Prog Org Coat 62:313

159. Labille J, Feng J, Botta C, Borschneck D, Sammut M, Cabie M, Auffan M, Rose J, Bottero J (2010) Environ Pollut 158:3482

160. Tablet L, Bussy C, Setyan A, Simon-Deckers A, Rossi MJ, Boczkowski J, Lanone S (2011) Part Fibre Toxicol 8:3

161. Zhang Y, Xu Y, Li Z, Chen T, Lantz SM, Howard PC, Paule MG, Slikker W Jr, Watanabe F, Mustafa T, Biris AS, Ali SF (2011) ACS Nano 5:7020

162. Baber O, Jang O, Baber D, Powers K (2011) Inhal Toxicol 23:532

163. Auffan M, Pedeutour M, Rose J, Masion A, Ziarelli F, Borschneck D, Chaneac C, Botta C, Chaurand P, Labile J, Bottero J (2010) Environ Sci Technol 44:2689

164. Reijnders L (2008) J Hazard Mater 152:440 